\title{
JÄRELDUSPÕHINE LÄHENEMINE EESTI KEELE PÕHIKÄÄNETELE
}

\author{
MERILIN MILJAN
}

\section{Sissejuhatus}

$\mathrm{K}$ äesolev artikkel on põhiosas ülevaade ingliskeelsetest artiklitest (Cann, Miljan 2012; Miljan, Cann 2013), kus keskendutakse põhjalikumalt käändekäsitusele teoreetilises keeleteaduses, tuuakse välja enimlevinud teoreetiliste lähenemiste piiratud võimalused kontekstist sõltuvate tõlgenduste kirjeldamisel ning pakutakse välja omapoolne lahendus, järelduspõhine lähenemine käänetele, kasutades selleks eesti keele kolme põhikäände, nominatiivi, genitiivi ja partitiivi analüüsi. Siinne eestikeelne ülevaade keskendubki nende kolme käände olulisematele nüanssidele järelduspõhisest lähenemisest lähtuvalt.

Oluline on rõhutada, et nii käesolevas artiklis kui ka ülalmainitud käsitustes vaadeldakse käändeid teoreetilise keeleteaduse ning eelkõige süntaksiteooriate kontekstis, mille väljundiks on formaalsed keelekirjeldusmudelid ning kus käände mõiste erineb oluliselt traditsioonilises grammatikas kasutatavast mõistest. Teisisõnu, enimlevinud ja peamised formaalsed keelekirjeldusmudelid (nt Chomsky generatiivne grammatika, leksikaalfunktsionaalne grammatika (LFG), optimaalsusteooria) põhinevad terviklause süntaksil, st on süntaksipõhised, ning nähtav morfoloogia on teisejärguline või siis omistatakse sellele ainult teatud funktsiooni nähtavaks tegemise roll (siit ka käände kirjeldus kui (omaduse) realiseerija ehk vormistaja). Üldisemalt vaadates on aga erinevus vormi ja sisu küsimuses: kui süntaksiteooriates on süntaks lahutatud semantikast, siis kirjeldavas (ja n-ö traditsioonilises grammatikas) vaadeldakse semantilisi ja süntaktilisi funktsioone enamasti koos. Seega, kui kirjeldava grammatika esmaseks eesmärgiks on nt teatud käändetunnuse erinevate funktsioonide loetelu, siis formaalsetes süntaksimudelites tuleb leida selline üldistusaste ehk süntaksireegel, mis tagaks selle käändetunnuse esinemise kõikides funktsioonides ning ei ala- ega ülegenereeriks käändetunnuse esinemist. Näiteks generatiivses transformatsioonigrammatikas (Chomsky 1981) on selleks otstarbeks kasutusel kolm eri tüüpi käänet: semantiline, leksikaalne ning strukturaalne (süntaktiline), mida võib vormistada, aga ei pruugi, morfoloogiline käändetunnus. Kui strukturaalse käände vormistamisega peaks kaasnema tähendusefekt, tuleb seda käsitada ikkagi süntaksi osana, nt leksikoni kuuluvatele elementidele teatud semantilisi tunnuseid (ingl features) postuleerides ja siis neid semantilisi tunnuseid ühildades või mitteühildades.

Paratamatult nõuab süntaksipõhine lähenemine kompromisse analüüsi detailsuse osas. Kui üldistada mingi tähendusefekt (nt partitiivi käändega kaasnev 'ebamäärase koguse' tõlgendus) kogu keele grammatikale (nt partitiiv markeerib piiritlematust), siis kahtlemata jääb tähelepanuta kontekstist 
lähtuv tähenduse varieerumine. Mida rohkem aga arvestada kontekstist tulenevate tõlgendustega (nt faktiga, et teatud verbidega annab partitiiv verbifraasile 'ebamäärase koguse' asemel hoopis imperfektiivse tähenduse), seda keerulisemaks muutub teooria või süntaksimudel (nt tuleb postuleerida erinevaid süntaktilisi mehhanisme, mis tagaks vastava tõlgendusega tunnuse esinemise vastavates kontekstides). Kuid alati leidub kontekst, kus vastav (abstraheeritud) tähendus ei tule esile või seda ei tajuta (vt nt Rajandi ja Metslangi (1979) arutelu määramata ja määratud objektist, kus tuuakse selgelt välja objektikäänete vaheldumisega seotud tõlgenduste varieerumised).

Nii ongi üheks peamiseks formaalsete keelekirjeldusmudelite eristamise kriteeriumiks see, mida antud mudel analüüsib, kui püüab keele kohta üldistusi teha: kas analüüsitakse lause lõplikku tähendust (ehk tõlgendust) või hoopis seda, kuidas vastava tõlgenduseni jõutakse. Need formaalsed keelekirjeldusmudelid, mis keskenduvad lause tähenduse ehk tõlgenduse analüüsile, teevad keele kohta üldistusi terviklause (või konstruktsiooni) tähendusest lähtuvalt. Näiteks on terviklauset analüüsides kogu olemasoleva info abil suhteliselt lihtne määratleda verbi argumentide nii süntaktilised kui ka semantilised rollid või kui on tegemist verbi argumendi käändevaheldusega, siis mis tõlgendus vastaval käändel on. Sellise analüüsi tulemuseks ongi keelekirjeldusmudelid, mis kasutavad üsna tugevat üldistusastet nii süntaktilisel kui ka semantilisel tasandil. Nendele teooriatele ei ole iseenesest midagi ette heita, kuid nende peamiseks probleemiks on, et kontekstist lähtuv varieerumine jääb enamasti tähelepanuta ning seda on ka raskem modelleerida.

Lähenemised, mis eeldavad, et inimkeele keeleline teadmine on sisuliselt oskus keelt kontekstis liigendada ajas lineaarselt kumuleeruva info põhjal, vt nt dünaamiline lähenemine (Kempson jt 2001; Cann jt 2005; Kempson jt 2011 jt), püüavad kirjeldada keelest arusaamise või tõlgenduseni jõudmise p r o t s e s s i vastandina lõpliku tähenduse analüüsile. Käesolevas artiklis kasutataksegi dünaamilise lähenemise ideid eesti keele põhikäänete kirjeldamiseks ning näidatakse lihtsustatud ning mitteformaalsel viisil, kuidas need käänded osalevad tõlgenduse p r o t s e s s i s. Kuna tegemist on kirjeldusega, kuidas tõlgenduseni jõutakse (ja mitte terviklause või -fraasi analüüsiga), siis on oluline ka selgitada, kuidas teatud tõlgendusteni jõutakse pragmaatilise järeldamise teel (siit ka nimetus järelduspõhine lähenemine).

Enne käändetemaatikasse laskumist on intrigeeriv esitada küsimus keeleanalüüsi metodoloogia kohta, mis hõlmab põhjuse ja tagajärje probleemi: kas kääne v o r m i s t a b vastava konstruktsiooniga kaasnevat tõlgendust või annab hoopis ise aluse vastavale tõlgendusele? Esimesel juhul on käände roll mingi omaduse passiivne realiseerija (ehk vormistaja), teisel juhul on käändel aktiivne roll süntaktilise ja semantilise tõlgenduseni jõudmisel (st kääne ise on info kandja). Käesolevas ülevaates argumenteeritakse viimase kasuks.

\section{Käände mõiste teoreetilises keeleteaduses}

Käände mõiste ning käände funktsioon keeles on olnud pidevalt süntaksiteooriate fookuses ning arutelu keskmes sellest ajast alates, kui generatiivne grammatika kerkis 1960. aastate alguses esile paljutähendava keeleteooriana. Kuid hoolimata ulatuslikust kirjandusest käände teemal teoreetilises keeletea- 
duses, on käände mõiste jäänud siiski ähmaseks (vt Butt 2006: 3) ning käände rolli mõtestamine erinevates teoreetilistes keelekirjeldusmudelites varieerub märkimisväärselt. Põhiküsimused, nagu miks käändeid üldse vaja on, pole veel rahuldavat vastust leidnud paljude keeleteadlaste hulgas, kes püüavad keelt modelleerida nt transformatsioonigrammatika teooriast lähtudes. Isegi küsimused, kas käänet analüüsida eelkõige süntaktilisena (Chomsky 1981) või ainult morfoloogiasse kuuluvana (Marantz 1991 jpt) või kas käänet tuleks hoopis vaadelda nii süntaksi kui ka morfoloogia komponendina, et paremini keelt kirjeldada (nt Baker, Vinokurova 2010), on jäänud veel vastuseta. Samuti kordub pidevalt küsimus, et kui käänet analüüsida ainult süntaksi osana (nn süntaktiline kääne), kas tuleks seda siiski kuidagi siduda ka semantikaga või piirduda pelgalt käände kui formaalse (st süntaktilise) tingimusena, mis võimaldab nihutamist. ${ }^{1}$

Enamikus süntaksiteooriates on valdav seisukoht, et grammatiline kää$\mathrm{ne}^{2}$ lihtsalt vormistab verbifraasi või muu süntaktilise teguri poolt omistatud süntaktilist funktsiooni. Teisisõnu, kääne pole midagi muud kui passiivne tunnus, mis muudab nähtavaks nimisõnale omistatud süntaktilise funktsiooni. Sisuliselt tähendab see seda, et käänet analüüsitakse kui grammatiliselt triviaalset nähtust: kääne ise ei tee midagi, selle omistab (või kontrollib seda, oleneb konkreetsest keelekirjeldusmudelist) mingi muu element (funktsionaalne/süntaktiline kategooria või verbifraas), et tagada mingi kitsenduse nõue. Sõltuvalt lähenemisest varieerub ka käände rolli mõtestamine oluliselt. Näiteks neis transformatsioonigrammatika teooriates, kus tuleb käänded derivatsiooni käigus kustutada või muud moodi elimineerida (sest semantiliselt neid tõlgendada ei saa ning seega ei kehti kääne vastuvõetava tunnusena nn loogilisel tasandil), käsitatakse käänet kui midagi mõttetut või ülearust, millest tuleb lause derivatsiooni käigus lahti saada. Morfoloogiliselt väljendatud grammatilised käänded ei puutu aga üldse asjasse, kuna need võivad keeles esineda, aga ei pruugi. Semantiliste käänete osas pole aga transformatsioonigrammatika raames välja pakutud ühtegi tõsiseltvõetavat teooriat. Ka põhjakeskses fraasistruktuurigrammatikas (ingl HPSG) on käändel passiivne roll, kuna fraasituum on see, mis määrab käände (ja sellega seotud omadused) oma laienditele. Lähenemistes, mis põhinevad erinevate tasandite (nt moodustajate, lauseliikmete, semantika ning diskursuse tasandite) ühendamisreeglitel, nagu leksikaalfunktsionaalne grammatika (LFG), on aga käände funktsioon keeles (kus see esineb morfoloogiliselt markeerituna) rohkem mõtestatud ning talle on antud n-ö kandvam roll. LFG keelekirjeldusmudelites kannab käändetunnus täiesti iseseisvalt infot selle elemendi süntaktilise funktsiooni kohta, millel ta esineb, st käänet ei omista verbifraas ega muu süntaktiline kategooria (vt Nordlinger 1988). Sellist käändekäsitust tuntakse konstruktiivse käände nime all ning on tõepoolest samm edasi käände rolli mõtestamisel formaalsetes süntaksiteooriates: kääne pole enam pelgalt alistusseose vormistaja, vaid määrab ise selle nimisõna või nimisõnafraasi süntaktilise funktsiooni,

\footnotetext{
${ }^{1}$ See küsimus oli eraldi teemana välja pakutud 5. Brüsseli generatiivse lingvistika konverentsil 2.-3. XII 2010. Teemapüstitus oli järgmine: Kas kääne on eranditult vaid nihutamist lubav tingimus (ingl formal licensing mechanism) või on see seotud ka semantikaga?

${ }^{2}$ Kääne, mida analüüsitakse grammatilise (vastandina semantilise) info realiseerijana. Süntaksiteooriates vastab sellele üldjuhul mõiste süntaktiline kääne, mis esineb peamiselt argumendi positsioonil või omistatakse komplemendile.
} 
milles esineb. Kuid siiski on Nordlingeri konstruktiivne kääne oma olemuselt ainult süntaktiline ning käände ainsaks ülesandeks on ühendada see fraas, milles ta esineb, elemendiga, millega too fraas on alistusseoses. Ka optimaalsusteooria keelekirjeldusmudelites (mis põhinevad kitsenduste hierarhial) ei piirne käände roll pelgalt alistusseose markeerimisega, kuid siiski ei ole kääne selles lähenemises oma olemuselt midagi muud kui teatud sisendi passiivne realiseerija või väljund.

Kõikides nimetatud lähenemistes on probleemiks asjaolu, et kuna nad analüüsivad käändeid süntaktilisest vaatepunktist, siis rakendatakse käändeid eristavat, mitte aga ühtset lähenemist, st postuleeritakse sünkretism (st ühe muutevormi põhjal kahe identse, kuid erineva funktsiooniga muutevormid) seal, kus see eriti põhjendatud ei ole. Teisisõnu, need lähenemised teevad rangelt vahet süntaktilisel (ehk grammatilisel) ning semantilisel käändekasutusel, sest süntaks tuleb semantikast lahus hoida. Transformatsioonigrammatikas omistatakse süntaktilised käänded teatud süntaktilises konfiguratsioonis kas verbi või mõne funktsionaalse kategooria poolt (nt verb omistab süntaktilise käände objekti positsioonil nimisõnafraasile ning finiitne fleksioon nominatiivi käände subjekti positsioonile). Semantilisi käändeid seostatakse aga konkreetset tähendust kandvate mitte-argumentidega, milleks on enamasti vabad laiendid (siit ka nimetus semantiline kääne). Näiteks võiks tuua eesti keele adverbiaalid (kuid sarnaseid juhtumeid esineb ka paljudes teistes keeltes), mis väljendavad aega, hulka või kogust. Adverbiaalidel analüüsitakse sama käänet sõltuvalt selle omistamisest kas argumendile või mitteargumendile kas grammatilisena, st objektikäändena näidetes $2,4,6$, või semantilise käändena näidetes 1, 3, 5 (vt lähemalt arutelu grammatilise ning semantilise käände eristamisest soome keele adverbiaalidel Nelson 1998; Kiparsky 2001; Svenonius 2002).

(1) Ma ootasin ühe minuti.

(2) Poiss sõi ühe jäätise.

(3) Ma ei oodanud (ühte) minutit-ki.

(4) Poiss ei söönud ühte jäätist-ki.

(5) Oota üks minut.

(6) Söö üks jäätis.

Põhimõtteliselt ei ole sünkretismi postuleerimine teoreetilises analüüsis problemaatiline, kui selline eristamine võimaldab välja tuua tõelised ja olulised reeglipärasused. Kuid paraku ei ole see alati nii, nagu selgub ka näidete 1-6 põhjal: ühe muutevormi põhjal kahe identse, kuid erineva funktsiooniga muutevormi eristamine hägustab üldistuste tegemist sellesama muutevormi kasutuse kohta ühes ja samas konstruktsioonis, olgu või tegemist grammatilise ning semantilise käändekasutuse eristamisega.

Käänete eristamine grammatilise ja semantilise kasutuse alusel eeldab, et kumbagi käändevormi analüüsitakse homonüümina (st tähendus ja funktsioon erineb, kuid vorm on sama). Kuna käänete sünkretism on üsna tavaline nähtus erinevates maailma keeltes, siis võib väita, et käändevormide homonüümia on täiesti õigustatud, et see peabki nii olema. Siiski on oluline siinkohal välja tuua, et sünkretismi rakendatakse vaid teatud käändeparadigma(osa)de puhul, mitte aga terves käändesüsteemis (vastasel juhul ei oleks sünkretism 
üldse nähtav). Kuid selline homonüümia, mille aluseks on ühe ja sama muutetunnuse eristamine grammatiliseks ning semantiliseks käändeks pelgalt sellesama käändetunnuse grammatilise ning semantilise kasutuse alusel põhjustab homonüümiat suures ulatuses. Tulemuseks on olukord, kus grammatilised üldistused, nagu näidetes 1-6 ülal, lähevad eranditult kaotsi või selliseid näiteid esitatakse kui seletamatuid erandeid (vt Nelson 1998; Kiparsky 2001; Svenonius 2002), samal ajal kui liiasus vohab morfoloogilisel käändesüsteemi tasandil ning käände enda mõiste muutub üha liigendatumaks ning seega ka hägusemaks.

Nagu ülal mainitud, tutvustatakse käesolevas ülevaates kardinaalselt erinevat käändeanalüüsi: järelduspõhist lähenemist (vt Cann 2007), mis ei postuleeri käändeid eraldi (abstraktsel) süntaksi tasandil ning seega ka mitte homonüümiat ega liiasust, vaid võtab käändeid nii, nagu need on, st nähtava morfoloogilise käändetunnuse kujul. Sellise analüüsi tulemusena on morfoloogiline käändetunnus tõsiseltvõetav iseseisev tunnus, aga mitte (abstraktse) süntaktilise käände morfoloogiline realiseerija (ehk vormistaja). Selline käände mõiste ümbermõtestamine aitaks seletada ka näiteid, mis on erinevates süntaksipõhistes käsitustes (aga eriti transformatsioonigrammatikas) osutunud problemaatiliseks kas käändevahelduse vaba varieerumise, süntaktilise ebamäärasuse $^{3}$ või n-ö mittetüüpilise käände esinemise tõttu subjektil (vt lähemalt Miljan, Cann 2013).

\section{Käändevaheldus eesti ja soome keeles: kuidas teoreetilised keele- mudelid seda analüüsivad}

\subsection{Subjekti ja objekti vormistamine ning käändevaheldus eesti keeles}

Teatavasti on eesti keeles rikkalik morfoloogiliselt väljendatud käändesüsteem. Käänete hulgas, mida kasutatakse süntaktiliste argumentide vormistamiseks (subjekt, objekt), ei ole morfoloogilist akusatiivi, kuigi eesti keelt peetakse nominatiiv-akusatiivseks keeleks. Objektargumenti võib vormistada kolm erinevat käänet: partitiiv (7), genitiiv (8) ja nominatiiv (9).

(7) Poiss sõi jäätist.

(8) Poiss sõi jäätise.

(9) Poiss ostis jäätised.

Subjektargumenti vormistab tüüpiliselt nominatiiv (7-9), kuid intransitiivsetes lausetes võib subjekt esineda ka partitiivi käändes (10).

(10) Külalisi saabus.

Seega võib käändevaheldus esineda mõlemal argumendil, nii subjektil kui ka objektil; samuti adverbiaalil nt genitiivi (11) ja partitiivi (12) vahel.

${ }^{3}$ Silmas on peetud selliseid näiteid, kus ilma konteksti teadmata on võimatu määratleda käändega markeeritud nimisõna funktsiooni, nt sõna selle funktsiooni lauses Orav viis selle käbi peidukohta (näide Roosmaa jt 2003; Müürisep 2007: 12). 
(11) Ta viibis Londonis nädala.

(12) Ta viibis Londonis nädalaid.

Partitiiviga vormistatud nimisõna tõlgendamine sõltub nii nimisõna tähendusest kui ka verbi (semantilistest) omadustest, millega partitiiviga markeeritud nimisõnafraas on alistusseoses, samuti kontekstiga seotud teguritest. Kui massisõna esineb objektargumendina, siis genitiiv märgib, et verbiga tähistatav sündmus on suunatud nimisõnafraasiga tähistatava entiteedi mingile kindlale hulgale, samal ajal kui partitiivi kääne viitab, et verbiga tähistatud tegevus puudutab (ainult) osa nimisõnafraasiga tähistatud kindlast entiteedist või tegevus on kestev nagu näidetes 7 ja 10 ülal. Mitmuses olevad nimisõnad käituvad samamoodi nagu massisõnad.

Oluline on siinkohal juhtida tähelepanu asjaolule, et kuigi eesti keele sõnajärg on suhteliselt vaba, ${ }^{4}$ esineb nende käänete vahel, mida kasutatakse süntaktiliste argumentide vormistamiseks (st subjekt, objekt), valdavalt mitmetähenduslikkus. See tähendab, partitiivi kääne võib vormistada nii objekti kui ka subjekti, nominatiivi kääne vormistab enamasti subjekti, kuid tihti ka objekti (nt impersonaali ja imperatiivi konstruktsioonis), genitiivi kääne vormistab nii nimisõnalise fraasituuma laiendeid (nt possessiivi) kui ka verbi laiendit (nt objekti). Seega on ilma lokaalset konteksti ning käändega vormistatud nimisõna tähendust arvesse võtmata üsna raske, kui mitte võimatu, määratleda, millist süntaktilist funktsiooni antud kääne parasjagu vormistab.

\subsection{Kuidas formaalsed keelekirjeldusmudelid soome keele käändeid analüüsivad? ${ }^{5}$}

Nagu juba ülal mainitud, püüab enamik formaalsetest keelekirjeldusmudelitest seletada käändevaheldust süntaktilisest vaatepunktist. Tihti võetakse appi abstraktse käände mõiste, mis on oma olemuselt täiesti süntaktiline (st seda võib vormistada ehk realiseerida morfoloogiline kääne, aga ei pruugi) ning sisuliselt samastatakse süntaktilise funktsiooniga, nt abstraktne akusatiivi kääne on üksüheses vastavuses objekti funktsiooniga ning abstraktne nominatiivi kääne on üksüheses vastavuses subjekti funktsiooniga. Sellise samastamise tagajärjeks ongi nt transformatsioonigrammatikas debatid teemal, kas ja milleks on käänet üldse vaja (vt jaotist 2). Transformatsioonigrammatika teooriates, mis hõlmavad soome keele grammatilisi käändeid, kirjeldatakse käände varieerumist objekti positsioonil just nimelt abstraktsete käänete abil: postuleeritakse süntaktiline (ehk abstraktne) partitiiv ning süntaktiline (ehk abstraktne) akusatiiv (vt Nelson 1995; Ritter, Rosen 2001; Svenonius 2002). Kuna mõlemad käänded on teatud kontekstis seotud ka semantiliste tõlgendustega, siis on lahenduseks pakutud, et käände omistab kas eraldi aspekti funktsionaalne kategooria või verbifraas, millel on teatud semantilised omadused: akusatiivi käände omistab teeline (perfektiivne) verbifraas ning partitiivi käände omistab markeerimata verbifraas, st ateeline (imperfektiivne) verbifraas (vt Nelson 1995; Kiparsky 2001; Ritter, Rosen 2001; Svenonius 2002). Kuna aga partitiivi käändega seostatakse ka muid tõlgendusi kui im-

\footnotetext{
${ }^{4}$ Siiski eelistatakse verbi teisel positsioonil lauses, vt Lindström 2006.

${ }^{5}$ Enamik läänemeresoome keelte käänete formaalseid keelekirjeldusmudeleid on soome keele käänete kohta. Seega saab vaid nende abil arvata, kuidas eesti keele käändeid kirjeldataks.
} 
perfektiivne aspekt ja kuna kääne määratakse süntaktiliselt, siis tuleb muude partitiivi tõlgenduste puhul rakendada teistsugust käändeomistust. Näiteks Paul Kiparsky (1998; 2001) pakub soome keele kohta välja kolm erinevat (süntaktilist) partitiivi, mille eristuse aluseks ongi nende omistamise viis: 1) partitiiv, mille omistab ateeline verbifraasituum (vt näide 7), 2) partitiiv, mille omistab null-kvantifikaator alistusseoses olevale nimisõnafraasile, nagu näites 13 , sest verbifraas ise viitab teelisele sündmusele, kuid nimisõnafraasil esineb partitiivi kääne, ning 3) partitiiv, mille omistab objektargumendile eituse tunnus (14).

(13) Ta leidis kulda.

(14) Ta ei joonud vett.

Genitiivi käände puhul aga eristatakse tihti kahte eraldi käänet: genitiivi, mida üksüheselt seostatakse possessiivi vormistamisega, ning genitiivi, mis realiseerib morfoloogiliselt akusatiivi käänet. Seega eeldatakse sünkretismi ainsuse genitiivi ning akusatiivi vahel (vt Ackerman, Moore 1999; 2001; Hiietam 2003; Baerman 2009; Caha 2009). Sellises analüüsis omistatakse possessiivi-genitiiv tavaliselt markeerimata käändena (ehk vaikimisi) nimisõnafraasisiseselt ning objekti-genitiivi omistamise üheks tingimuseks on subjektil esinev nominatiivi kääne (vt Kiparsky 2001). Semantilist varieerumist partitiivi ning objekti-genitiivi vahel reguleerib sel juhul verbifraasi semantiline omadus (nt aspekt), nagu juba ülal mainitud. Kuid eristades süntaktiliste funktsioonide alusel ühest käändevormist mitu erinevat käänet (nt possessiivi, akusatiivi, postpositsiooni jne), ei suudeta siiski selgitada, miks genitiiv, olles grammatiline (ehk süntaktiline) kääne, esineb adverbiaalidel, nagu näidetes $1,3,5$. Ja kui tahetaks võtta arvesse kõik genitiivivormiga väljendatud süntaktilised funktsioonid, peaks käänet süntaktilisest vaatepunktist analüüsides hakkama suurel hulgal homonüümiat postuleerima. Seega, kui kirjeldada käändeid süntaktilisest vaatepunktist, ei saa ükski keelekirjeldusmudel hakkama, ilma et peaks lisaks grammatilise ning semantilise käände kasutamise eristamisele eristama ka ühte ja sama käänet selle grammatiliste (või siis hoopis semantiliste) tõlgenduste alusel. Kuid selline ühe käände eri vormide postuleerimine (st homonüümia) muudab käände funktsioonist arusaamise ähmasemaks, rääkimata paradigmaatiliste seoste selgitamisest teiste käänetega.

\section{Järelduspõhine lähenemine käänetele}

Eesti keele põhikäänete ning subjektil ja objektil esineva käändevahelduse ${ }^{6}$ analüüsile tuginedes väidavad Cann ja Miljan (2012) ning Miljan ja Cann (2013), et on võimalik luua ka selline käändeteooria, kus ei ole vaja homonüümiat postuleerida ning millega saab ülaltoodud näiteid ilma liiasust tekitama-

\footnotetext{
${ }^{6}$ Käändevahelduse all mõistetakse tavaliselt erinevate morfoloogiliste käänete esinemist verbi argumendil, kas siis subjektil või objektil. Käänded, mis võivad käändevahelduses osaleda, on keeliti erinevad, nagu ka käändevaheldusest tingitud tõlgenduserinevused. Tõlgenduserinevused võivad olla seotud käändega markeeritud nimisõnafraasiga (nt definiitsus või agentiivsus), predikaadi tõlgendusega (nt aspekt või modaalsus), mõne diskursusega seotud funktsiooniga (nt fookus või rõhutamine). Võib ka nii olla, et käändevaheldus ei ole üldse seotud mitte mingi ilmse tõlgenduserinevusega, vaid seda seostatakse mõne stiililise variatsiooni või süntaktilise alistusseose väljendamisega.
} 
ta seletada. Seda aga juhul, kui omistada nähtavale morfoloogilisele käändele suurem roll ning morfosüntaktilisele käändeanalüüsile läheneda morfoloogilisest vaatepunktist süntaktilise asemel. Grammatilist käänet ei analüüsitaks kui süntaktiliste üksuste omaduste passiivset realiseerijat, vaid kui n-ö morfoloogilist tunnust, mis lisab iseseisvalt süntaktilise ja/või semantilise informatsiooni konstruktsioonile, kus ta esineb. Oluline on siinkohal rõhutada, et mõnedel käänetel võib see informatsioon olla alamääratletud - omadus, mida kasutatakse laialdaselt arvutilingvistikas ning mis võimaldab kirjeldada kontekstist lähtuvaid tõlgendusi. Alamääratluse mõiste selgitamiseks saab paralleeli tõmmata deiktiliste sõnadega (homme, tema, siin jne), mille konkreetne tähendus (käänetel siis tegelik süntaktiline ja/või semantiline funktsioon) selgub alles kontekstis.

Käändetunnuse poolt lisatav spetsifikatsioon oleks järelduspõhise tõlgendusprotsessi sisendiks. St lause tegelik tõlgendus tuletatakse käändega lisatud informatsioonist üheskoos selle nimisõna(fraasi) semantiliste omadustega, millel antud kääne esineb, või üheskoos selle verbifraasi süntaktiliste ja semantiliste omadustega, kus kääne esineb, või üheskoos diskursusega või kõikide nende loetletud tegurite kombinatsioonist. Seega käändetunnusega nimisõnafraasi k onkreetne süntaktiline ja/või semantiline funktsioon määratakse vastastikmõjus kas: 1) käändetunnuse spetsifikatsiooniga, 2) käändega markeeritud nimisõna tähendusega, 3) predikaadi tähendusega, mille argument on käändetunnusega nimisõnafraas, 4) teiste kontekstist sõltuvate teguritega. Sellest järeldub, et käändetunnuse tegelik tõlgendus võib konstruktsiooniti varieeruda üksnes süntaktilisest tõlgendusest kuni erinevate semantiliste ning pragmaatiliste tõlgendusteni. Siit selgub ka, et järelduspõhises lähenemises taandub grammatiliste ning semantiliste käänete vaheline erinevus informatsiooni hulga erinevusele, mida kääne lisab ning mis võib varieeruda sõltuvalt kontekstist. Ka ei saa välja tuua universaalseid üldistusi käändetunnuste kohta, sest nagu ka Martin Haspelmath (2007) väidab, sõltuvad need konkreetsest keelest: eesti keele genitiivi funktsioonid ei ole üksüheselt samad, mis saksa keele genitiivil.

Kuigi käesoleva ülevaate eesmärgiks on jääda võimalikult mitteformaalseks ning tutvustada paradigmaatiliselt erinevat käändekäsitust, saab järgneva mitteformaalse analüüsi esitada ka formaalse keeleteooria vormis, kasutades selleks dünaamilise süntaksi (Kempson jt 2001; Cann jt 2005; Kempson jt 2011) esitusviisi, kus väljendid esitatakse epsilonarvutuse (Hilbert, Bernays 1939) kujul ning keele-elementide tõlgenduste kontekstisõltuvust kasutatakse kui vahendit, mille abil saab määratleda kitsendused nii distributsiooni kui ka tõlgenduste kohta. Üldisemalt kirjeldades, nagu juba ülal mainitud, on dünaamiline süntaks formaalne keelemudel lausungite kirjeldamiseks ning selle põhihüpoteesiks on, et inimkeele keeleline teadmine on sisuliselt oskus (suulist) keelt (ehk lausungeid) kontekstis liigendada (st määrata sõnade süntaktilised funktsioonid ja tähendus) ajas lineaarselt kumuleeruva konteksti ehk info põhjal. Sellise lähenemise eeliseks on, et ta võimaldab eksplitsiitselt näidata, kuidas järk-järgult jõutakse sõnajada (ehk lause) lõpliku tõlgenduseni, kasutades selleks sõna sõna haaval saadud semantilist ja grammatilist infot. Samuti ei eristata süntaktilist infot semantilisest eraldi tasandite või moodulitena (nagu LFG-s või transformatsioonigrammatikas), vaid erinevat infot kasutatakse samaaegselt. Samas on aga oluline välja tuua, et selline 
teistsugune lähenemine käänetele, nagu siin tutvustatakse, ei eelda tingimata dünaamilise süntaksi raamistikku, viimane on vaid vahend formaalse keelekirjeldusmudeli kujundamiseks.

Järgnevalt näidatakse, kuidas võiks analüüsida eesti keele põhikäändeid järelduspõhisest vaatepunktist.

\section{Eesti keele põhikäänded järelduspõhisest vaatepunktist lähtuvalt}

Kui läheneda eesti keele põhikäänetele morfoloogilisest perspektiivist (vastandina süntaktilisele) ning käsitada käändeid järelduspõhiselt, siis on eesti keeles ainult üks täiesti süntaktiline (ehk grammatiline) kääne. See kääne on genitiiv, mis on sisuliselt obliikvakääne ning markeerib mittesubjektilist alistusseost mis tahes fraasituumaga. Võib väita, et genitiiv täidab eesti keeles seda funktsiooni, mida akusatiiv täidab nendes keeltes, kus ta esineb. ${ }^{7}$ Partitiivi kääne aga käitub selle analüüsi kohaselt tõelise partitiivi käändena kogu oma kasutusalas, kuigi partitiivne tähendus võib olla hägustunud või isegi kaduma läinud, sõltuvalt kontekstilistest teguritest. Nominatiiv on aga lihtsalt käände(tunnuse) puudumine, mida ei seostata ühegi kindla süntaktilise funktsiooni või semantilise tõlgendusega. Sellest kõigest lähemalt järgnevates alapeatükkides.

\subsection{Miks käsitada partitiivi partitiivina?}

Kuigi enamik soome keele formaalseid süntaksimudeleid kirjeldavad partitiivi käänet vaikimisi omistatud süntaktilise (ehk grammatilise) objekti- või komplemendikäändena, ei põhjenda need, miks partitiivi käänet seostatakse süntaktilise info väljendamisega. Ainus põhjalikum seletus on Paul Kiparskyl, kuid selles tõestatakse partitiivi analüüsi objektikäändena vaid näidates, et argument, millel partitiiv esineb, on objekt, aga mitte vaba laiend (Kiparsky 1998: 276). Samamoodi saaks tõestada ka, et partitiiv on subjektikääne või siis hoopis vaba laiendi kääne. Seepärast väidavad Miljan ja Cann (2013), et partitiivi kääne ise ei lisa süntaktilist informatsiooni. Põhiargumendiks on, et partitiivi kääne varieerub teiste käänetega nii objekt- kui ka subjektargumendil, lisaks veel vabadel laienditel (võimalikku seletust, miks partitiiviga markeeritud argumenti seostatakse objektifunktsiooniga, vt lähemalt Miljan, Cann (2013).

Nagu ülal mainitud, partitiivi käändes oleva nimisõna tõlgendamine sõltub nii verbi kui ka nimisõna enda tähendusest. Näiteks kui ainesõna esineb objekti funktsioonis, siis partitiivi saab tõlgendada kui nimisõnafraasi denotaadi ebamäärase koguse väljendajat või siis verbifraasi imperfektiivse aspekti väljendajat. Mitmuses olevad sõnad käituvad samamoodi, et on võimalus tõlgendada nimisõna denotaati kas ebamäärase hulgana või siis verbifraasi imperfektiivsena.

Ainsuses olevate loendatavate nimisõnade korral varieerub partitiivi käände vastuvõetavus suuresti, sõltudes sellest, kas vastavat asjasõna saab

\footnotetext{
${ }^{7}$ Seda seisukohta toetab ka Helena Metslangi (ilmumas) korpusuurimus, mis analüüsis grammatiliste käänete kasutust morfoloogilisest vaatepunktist. Selgus, et $100 \%$ genitiiviga markeeritud argumentidest olid objekti funktsioonis, $66 \%$ nominatiivi vormis argumentidest olid subjekti funktsioonis ning $58 \%$ partitiiviga märgitud argumentidest olid objekti funktsioonis.
} 
tõlgendada ainesõnana. Näites 15 on partitiiviga märgitud subjekt ootamatu ning ilma täiendava kontekstita grammatiliselt vastuvõetamatu.

(15) Laual oli \#raamatut.

Kui seesama asjasõna esineb aga partitiivis koos transitiivse verbiga, on lihtne eirata asjaolu, et seda on raske tõlgendada koos partitiiviga, sest verbi leksikaalsed omadused lubavad meil seda partitiivset asjasõna tõlgendada kui protsessi ehk lõpetamata tegevust (näide 16) (vt lähemalt selle kohta jaotises 5.2).

(16) Peeter luges raamatut.

Kuid mitte alati ei ole transitiivse verbi omadused sellised, mis võimaldaks partitiiviga markeeritud ainsuse asjasõna tõlgendada sobivana ning tulemuseks on siiski vastuvõetamatu kombinatsioon (näide 17). Verbid, mis selliselt käituvad, tähistavad hetkelisi sündmusi, millega kaasneb seisundimuutus (nn kulminatsiooniverbid, vt Moens, Steedman 1988; saavutusverbid, vt Vendler 1967); seega puudub võimalus neid verbe protsessina tõlgendada (kui just ei muudeta nendega kaasneva nimisõna sõnaklassi asjasõnast ainesõnaks).

(17) Peeter leidis \#raamatut.

Ainsuses olevad asjasõnad, mis kannavad partitiivi käänet, esinevad aga vabalt koos nn sooritusverbidega, mille puhul genitiivi kääne väljendab perfektiivset (näide 18) ning partitiivi kääne imperfektiivset sündmust (näide 19).

(18) Peeter ehitas suvila aastaga.

(19) Peeter ehitas suvilat terve aasta.

Lisaks teatud liiki verbide semantilistele omadustele, mis võimaldavad tõlgendada ainsuslikku asjasõna partitiivis, täidab sama ülesannet ka sõnaklassi sundmuutmine asjasõnast ainesõnaks. Kui ainsuslikku asjasõna on partitiivi käändes võimalik tõlgendada ainesõnana (näide 20) või liiginimetusena (näide 21 ), on partitiiv täiesti vastuvõetav (vrd näiteid 15 ja 20 ).

(20) Seda raamatut vedeles kõikjal.

(21) Aednik istutas seda roosi kõikjale.

Partitiivi käändes oleva nimisõna tõlgendamine sõltub seega nii predikaadi kui ka nimisõna enda tähendusest. Kui aga keskenduda partitiivi ja genitiivi ning partitiivi ja nominatiivi käändevaheldusele, tõstatub küsimus, mis täpsemalt määrab käändevahelduse ja selle tõlgendused. Võiks küsida veel lihtsameelsemalt, et miks eesti keeles (ja ka nt soome keeles) on käändevaheldusega seotud tõlgendused seotud just ebamäärase ja määratletud hulgaga ning lõpetatud ning lõpetamata tegevusega, aga mitte näiteks elususe või agentiivsuse või hoopis modaalsusega? Cann ja Miljan (2012) väidavad, et eesti keeles esinevate partitiivi ning genitiivi ja partitiivi ning nominatiivi käändevahelduste tõlgendused saab omistada partitiivi enda tähendusele 
ning et käändevahelduse tulemusena tekkinud tõlgendusi saab seletada järelduspõhisest pragmaatikast lähtuvalt, järgides näiteks relevantsusteooriast (Sperber, Wilson 1995) pärinevaid ideid.

\subsection{Partitiivi spetsifikatsioon}

Nagu juba ülal mainitud, saab järelduspõhise lähenemisega analüüsida partitiivi tõelise partitiivi käändena, ${ }^{8}$ mille partitiivne tähendus võib olla küll kohati hägustunud või teatud konstruktsioonides isegi kaduma läinud, kuid on sellest hoolimata aldis semantilisele ja pragmaatilisele ekstensioonile vastastikmõjus selle nimisõna tähendusega, kus partitiiv esineb, ning verbi semantiliste omadustega, mille argument on partitiivi käändega markeeritud nimisõna, ja samuti teiste kontekstiliste teguritega. Semantiline spetsifikatsioon, mille partitiivi kääne lisab sõltumatult muudest teguritest lauses, on partitiivi põhitähendus, st Cann ja Miljan (2012) lähtuvad hüpoteesist, et partitiiv tähendab järgmist:

(22) 'pärisosa X-st' = 'ebamäärane hulk X-st' (kus X = nimisõnafraasi denotaat)

Seda partitiivi tõlgendust saab vahetult näha fraasides 23 ja 24 :

(23) tükk kooki

(24) osa külalisi/vett

Kui oletada, et partitiivi kääne omistab semantilise partitiivi tähenduse nimisõnafraasile, kus ta esineb, siis mitmuses olevate sõnade ebamäärase hulga tõlgendus tuleneb otseselt partitiivist: kuna osa mingist kogumist/hulgast sisaldab ka tähendust, et 'mõni või veidi (aga mitte kõik)' sellest kogumist/ hulgast, st 'ebamäärane kogus'. Võib ju küsida, mille osa need maasikad siis on näites 25 või üliõpilased näites 26 . Elatiivi kääne mängib selle mõistmisel olulist rolli. Näites 27 erineb sõna maasikad näites 25 olevast sõnast ainult selle poolest, et on elatiivi käändes, aga mitte partitiivis. Kuid näite 27 tõlgendus on seotud mingi kindla või teatud kogusega, millest maasikaid maitsti.

(25) Maitsesin maasikaid.

(26) Anul on suurepäraseid üliõpilasi.

(27) Maitsesin maasikatest vaid mõnda.

Seega saame järeldada, et kui elatiivi kääne märgib mingit konkreetset hulka, millest midagi on valitud, siis partitiivi kääne valib geneerilisest ehk liigi hulgast, mis laieneb maasikate hulgale, mis on (hetkel) saadaval. Selline tõlgendus on üsna tavaline teistes keeltes, eriti selgelt aga romaani keeltes, nt prantsuse keeles, kus indefiniitseid loendumatuid ja mitmuslikke referente väljendatakse partitiivse/genitiivse konstruktsiooniga (nimetatakse ka eessõnaks, de) koos geneerilise definiitse artikliga. Näiteks J'ai bu du vin 'Ma jõin veini' tähendab sõna-sõnalt 'Ma jõin natuke veinist (liiginimetusena)'. ${ }^{9}$ Partitiivi kasutamine eesti keele mitmuses olevate nimisõnade puhul näib täpselt

${ }^{8}$ Ajalooliselt on partitiivi kääne kujunenudki lokaalsest separatiivi käändest, vt Rätsep 1977, 1979.

${ }^{9}$ Vt ka Lyons (1999: 100-103), kus arutatakse seda teemat seoses prantsuse ja soome keelega. 
sama. Seetõttu oletavad Cann ja Miljan (2012), et partitiiv koos spetsiifilise entiteediga annab range pärisosa tõlgenduse sellestsamast entiteedist, samas kui mittespetsiifilise nimisõna puhul saame pärisosa tõlgenduse liiginimest (või kõikide entiteetide hulgast, mis vastavad antud kirjeldusele). Sellise partitiivi tähenduse tõlgendamisega on lihtne ka seletada sõnaklassi semantilise sundmuutmise näiteid, nagu näites 28 .

(28) Aednik istutas seda roosi kõikjale.

Selles näites näib tegemist olevat spetsiifilise roosiga partitiivi käändes, kuid tõlgendus on veider, sest ükski normaalne aednik ei istuta (ühe) konkreetse roosi tükke suvaliselt igale poole. Kuid fakt, et partitiiv võib anda ka tõlgenduse 'osa X-st, kus X on nimisõnafraas liiginimetusena', kui tegemist on määratlemata nimisõnaga, lubab meil teha otsese järelduse, et see on '(osa) sellest roosiliigist'.

Oma hüpoteesi kinnituseks partitiivi tähenduse kohta märgivad Cann ja Miljan (2012), et kui eeldada, et partitiiv väljendab 'ebamäärast kogust' ning opereerida selle mõistega, siis on üsna raske seletada, kuidas 'ebamäärase koguse' mõistest saaks tuletada '(päris)osa X-st' tõlgenduse. ${ }^{10}$ 'Ebamäärane hulk' ei välista millegi koguhulga valimist: terve kook on samaaegselt ebamäärane kogus kooki või koogist, kuid ei ole (päris)osa sellest koogist. Tegelikult tundub, et kui väita, et partitiiv väljendab 'ebamäärast kogust', eeldatakse siiski selliste näidete partitiivset (osatähenduse) tõlgendust, kuna peetakse silmas 'ebamäärast kogust, aga mitte kõike', ${ }^{11}$ mis aga tegelikult ei tähenda muud kui pärisosa tõlgendust millestki, st partitiivset tõlgendust.

Kuidas aga seletada teisi, verbifraasiga seotud partitiivi tõlgendusi? Cann ja Miljan (2012) pakuvad, et need kerkivad esile läbi kahe järelduse. Esimene järeldus (29) hõlmab fookuse nihutamist tähenduselt '(päris)osa millestki' tähendusele 'mitte kõik (millestki)', mis on tähenduse '(päris)osa millestki' kaastähendus:

(29) '(päris)osa X-st' > skalaarne implikatuur: 'mitte kõik X-st'

Nii muutub näites 30 fookus nendelt külalistelt, kes on juba saabunud, nendele külalistele, kes veel ei ole saabunud. Teisisõnu, muudetakse fookust tõlgenduselt 'Osa külalisi / mõned külalised on saabunud' tõlgendusele 'Mitte kõik külalised on saabunud'.

(30) Külalisi saabus.

Selline pragmaatiline fookuse nihe on aga vastastikmõjus verbi enda semantikaga. Verb saabuma on nn kulminatsiooniverb, millega tähistatav sündmus koosneb algusseisundist ning tulemusseisundist. Kui on arvukalt saabumisi (mis on tõenäoline mitmuses subjekti puhul), saab sündmuse algusseisundit tõlgendada kui protsessi (Rothstein 2004), mis koosneb üksikutest saabumistest ja tulemusseisundist kui lõppseisundist, mille puhul on kõik saabumised ära toimunud (sellepärast saab seda verbi liigitada sooritusverbi-

\footnotetext{
${ }^{10}$ Samuti tuleb märkida, et '(päris)osa millestki/X-st' on selgelt semantiline termin ehk definitsioon, samas kui 'ebamäärane kogus' seda ei ole.

${ }^{11}$ Vastasel juhul kasutataks muud käänet, nt genitiivi.
} 
de hulka). Kuna näites 30 antakse partitiivi abil selgelt edasi, et ainult mõned, aga mitte kõik külalised on saabunud, siis järeldub sellest, et kogu saabumise sündmus ei ole veel lõppenud. Seega lause fookus nihkub käimasolevale protsessile, mis koosneb eraldi saabumistest ning seeläbi saadakse imperfektiivne tõlgendus. Ehk teisisõnu, verbifraasi imperfektiivsus järeldatakse järgmiselt:

(31) 'mitte kõik X-st' > 'mitte kõik Y-st' (X = NP denotaat; Y = verbiga tähistatud sündmus)

Seesama hüpotees selgitab ka ainsuses olevate asjasõnade käitumist koos partitiivi käändega. Tegevus näites 16, milles Peeter luges 'osa raamatust', sisaldab ka tähendust, et Peeter luges 'mitte kogu raamatut' ja seega raamatu lugemise protsess on jätkuv ning tõlgendus jällegi imperfektiivne. Sama kehtib ka sooritusverbide nõutud imperfektiivse tõlgenduse kohta, kui ainsuse asjasõna on partitiivis. Näiteks kui lauses 19 pole veel kogu suvila ehitatud, siis järelikult Peeter ikka veel ehitab seda suvilat. Siin tuleks jällegi märkida, et üsna raske oleks selline tõlgendus tuletada partitiivist, mida seostatakse 'ebamäärase hulgaga' ning millega ei saaks rakendada '(päris)osa millestki' tõlgendust.

Küsimus, mis aga kahtlemata esile kerkib, on järgmine: kui imperfektiivsuse ja ebamäärase hulga tõlgendused tuletatakse partitiivi käände tähendusest, mis on siis genitiivi ja nominatiivi käände semantiline panus? Ja miks need kaks täiesti erinevat käänet käituvad sarnaselt, märkides perfektiivsust ehk lõpetatud tegevust? Muidugi on võimalik, et need omadused tulenevad otse genitiivi ja nominatiivi semantikast. Kuid sel juhul oleks üsna keeruline selgitada, miks nii objekti- kui ka mitteobjektikäändel on sarnased tõlgendused, kuigi süntaktiliselt käituvad nad täiesti erinevalt.

Järelduspõhisest pragmaatikast lähtuvalt saab aga seda nähtust seletada paradigmaatilise vastanduse kujunemise kaudu: käänete paradigmas on diakrooniliselt kujunenud vastandused partitiivi tõlgendustele. Näiteks Grice'i ja uus-Grice'i pragmaatikas kaasneb valikuga mingi väljendi kasutamise ja mittekasutamise vahel lisatähendus ehk implikatuur. Kui seda ideed käändevaheldusele laiendada, siis saab oletada, et partitiivi tähendus '(päris)osa $\mathrm{X}$-st' tõstab esile võimaliku vastanduse tähendusega 'kogu X'. Nii et isegi kui genitiiv või nominatiiv on mõnes konstruktsioonis vaikimisi või grammatiliselt määratud kääne, millega ei seostu mitte mingi semantiline tõlgendusefekt, siis niipea, kui neid käändeid kasutatakse partitiiviga vahelduvas konstruktsioonis, millega seostuvad partitiivsuse tõlgendused, siis partitiivi käände mittekas u t a min e samas konstruktsioonis annab märku varjatud vastandtähendusest, mida seostatakse nende käänetega, mis varieeruvad või vahelduvad partitiiviga. Sellest tulenevalt hakatakse partitiivile vastanduvat tähendust 'kogu X' seostama partitiivi mittekasutamisega, st mittesubjekti käände genitiivi ning subjektikäände nominatiiviga. Selline seletuskäik ennustab ka perfektiivse aspekti tõlgendust nendes kontekstides, kus partitiiv annab imperfektiivse tõlgenduse, sest fookus nihkub nüüd predikaadiga tähistatud liitsündmuse lõpetatusele. ${ }^{12}$ Seega väidavad Cann ja Miljan (2012), et morfosüntaktiliste elementide teatud pragmaatilised tõlgendused ei pärine

${ }^{12}$ Liitsündmuse all mõeldakse siin sündmusi, millele enamasti viitavad sooritusverbid. Nimetus liitsündmus lihtsalt täpsustab, et tegemist on kompleksse sündmusega, mis koosneb protsessist ning tulemusseisundist (vt Rothstein 2004, ingl complex event). 
nende enda tähendusest või kasutusest, vaid nende (käände)tunnuste tähendusest, millega neid vastandatakse.

Kinnitust sellele hüpoteesile pakuvad ka laused, kus esineb transitiivne verb ning partitiivi ja genitiivi käändevaheldus on vaba:

(32) Teet tellis seapraadi/seaprae..$^{13}$

(33) Korrigeerisime maksegraafiku/maksegraafikut. ${ }^{14}$

Nendes näidetes ei ole järelduspõhisel tõlgendusel sellist tugevat semantilist efekti ning tulemuseks on kontekstid, kus käändevaheldus on vaba. Seega ei erine oma tõeväärtuselt laused nagu Teet tellis seapraadi ning Teet tellis seaprae (nt restoranis). Sama kehtib ka näite 33 kohta, kus minevikus väljendatud erinevus kogu maksegraafiku või ainult selle osa korrigeerimise vahel ei oma tähtsust, kui just diskursuse fookus ei keskendu faktile, kas maksegraafik on täielikult muudetud või mitte. Objektargumendi vaba käändevaheldus esineb enamasti siis, kui verbi omadused ei lase selgelt määratleda, mis tüüpi sündmust nad tähistavad, nagu näidetes 32 ja 33; või kui sellega väljendatud kontrast on ebaoluline suhtlusaspektist vaadatuna (nt verbid, mis väljendavad soovi, tahet või kavatsust (vt Erelt jt 2007: 475). Seega mitte kõik käändevahelduse valikud ei lähtu grammatikast, toetades hüpoteesi, et kääne lisab informatsiooni sõltumatult teistest süntaktilistest üksustest ega ole vaid teiste üksuste poolt omistatud passiivne vormistaja. Huvitav on aga märkida, et isegi verbide puhul, mis tavaliselt ei näita mingit eelistust objektikäände valikus, põhjustab määruse lisamine teatud käände eelistamist. Näiteks kestvust väljendava määruse lisamine lauses 34 määrab, et objektargument peab olema partitiivis, sest kestvust väljendav määrus toob esile imperfektiivse tõlgenduse. Kui aga verbi laiendada mõne teise määrusega, nt sellisega, mis annab tegevuse lõpetatuse tõlgenduse, siis partitiivi ei saa kasutada (näide 35).

(34) Korrigeerisime maksegraafikut/*maksegraafiku pool päeva.

(35) Korrigeerisime maksegraafiku/*maksegraafikut poole päevaga.

Nii et partitiivi käändevaheldust saab seletada käände enda semantikaga, kasutades selleks pragmaatilisi järeldusi käände enda tähendusest, mille tulemuseks on erinevad tõlgendused erinevates kontekstides. Kuidas aga seletada partitiivi kasutamist eituse puhul, nagu näites 36, mis tundub olevat täielikult süntaktiline nähtus?

(36) Ta ei kallanud vett klaasi.

Kuigi ei saa taganeda tõsiasjast, et partitiivi esinemine eituse mõjualas o n süntaktiline fakt, ${ }^{15}$ saab sellegipoolest pragmaatilise järeldamise abil seletada, miks selline kasutus on üldse tekkinud. Teatud Austraalia keeltes on täheldatud, et käändetunnustel, nt ergatiivil, võivad kujuneda teatud diskursuse funktsioonid nagu fookuse või emfaasi markeerimine (McGregor 1998; Pensalfini 1999). Kuigi diskursuse ning käände vastastikmõju pole veel eriti põhjalikult uuritud (siiski vt Barđdal, Chelliah 2009), usuvad Cann ja Miljan (2012), et partitiivi kasutamine koos eitusega on motiveeritud just diskur-

${ }^{13}$ Rajandi, Metslang 1979.

${ }^{14}$ Erelt jt 2007: 474.

${ }^{15}$ See võis kujuneda ka kontaktkeelte mõjul (vt Koptjevskaja-Tamm, Wälchli 2001). 
susest. Nad püstitavad hüpoteesi, et partitiivi kasutamine eituse kontekstis arenes just eituse fookusesse tõstmisest või selle emfaasist. Kui objektil ei kasutata ootuspärast genitiivi käänet, vaid hoopis partitiivi, tõuseb fookusesse objektargumendi denotaadi osatähendus. Näites (36), kus on partitiivi käände tõttu tegemist nimisõna vesi liigi või geneerilise tõlgendusega, saame tõlgenduse 'Ta ei kallanud osa seda (liiki) vett klaasi', millega kaasneb tähendus, et mingisugust vett ei valatud klaasi. Seda näidet saab tõlgendada ka kui 'Ta ei valanud (mitte ühtegi) tilka vett klaasi'. Mitmuses olevate asjasõnade puhul kehtib samasugune tõlgendus. Seega näite 37 tõlgendus oleks 'Ma ei maitsenud osa maasikaid [liiginimetusena]', millest saab tuletada ka tõlgenduse 'Ma ei maitsenud (mitte ühtegi) maasikat'. ${ }^{16}$

(37) Ma ei maitsenud maasikaid.

Eelnevat hüpoteesi toetab kontrastiivse eituse käändekasutus. Näitest 38 selgub, et kui ei eitata objektargumendi olemasolu, on objektikäändeks neutraalne genitiiv.

\section{(38) Ta ei ostnud mitte maasturi vaid paadi. ${ }^{17}$}

Ülaltoodud näiteid silmas pidades saab oletada, et partitiivi kasutamine eituse mõjualas on kujunenud tavalise grammatiseerumisprotsessi tulemusena ning on pidevalt laienenud, kuni on muutunud (suvaliseks) süntaktiliseks faktiks eesti keeles (ja tema kontaktkeeltes), et eituse mõjualas tuleb kasutada partitiivi käänet. ${ }^{18}$

Seega saab partitiivi käändevaheldust seletada (mitte ainult kirjeldada) käände põhitähendusest lähtuvate pragmaatiliste järeldustega, millest saab omakorda tuletada aspekti ja diskursusega seotud tõlgendused. Need tõlgendused tuletatakse nimisõna tähenduse, sellel esineva käände ja verbi omaduste vastastikmõjust. Samuti väidavad Cann ja Miljan (2012), et partitiivi paradigmaatiline vastandamine genitiivi ja nominatiiviga on põhjuseks, miks neid käändeid seostatakse just selliste tõlgendustega nagu lõpetatus (perfektiivsus) ja koguhulk. Neid tähendusi pole vaja genitiivile ja nominatiivile eraldi omistada, kuna need tõlgendused on oma olemuselt pragmaatilised, tingitud vastandamisest partitiivi käändele, mis kannab tähendust.

\subsection{Genitiiv}

Eelnevast selgus, et morfoloogilisest perspektiivist vaadatuna ning järelduspõhisest analüüsist lähtuvalt on eesti keeles genitiivi kääne ainus, mis on otseselt seotud süntaktilise info väljendamisega. Teisisõnu, genitiivi kääne markeerib sõnal, millel esineb, et see sõna on mitte-subjektilises alistusseoses fraasipõhjaga (vt sellise genitiivi analüüsi põhjendust Miljan ja Cann 2013):

\footnotetext{
${ }^{16}$ Siinkohal võiks osutada sarnasusele emfaatlilise eitusega, mida väljendavad konkreetsed leksikaalsed sõnad, nagu 'tilk', 'tükk' jne prantsuse keele eituse (ne) ... pas kujunemisel hilisladina keelest ne passum 'mitte sammugi' või murdeprantsuse keeles ne ... mie väljendist ne mica 'mitte piiskagi' (vt ka Metslang 1997).

${ }^{17}$ Erelt jt 2007: 473.

${ }^{18}$ Siinkohal oleks paslik juhtida tähelepanu sellele, et kui eeldada, et partitiiv väljendab 'ebamäärast hulka', siis oleks üsna raske selgitada partitiivi kasutuse võimalikku kujunemist sellest mõistest.
} 
Kuna genitiivi kääne määrab ainult ü $l d$ i s e alistusseose fraasipõhjaga, siis missuguse alistusseosega täpsemalt on tegemist, sõltub juba argumendi või laiendi ning fraasipõhja omavahelisest kombinatsioonist. Näiteks alltoodud näidetes ei ole muud erinevust genitiivi kasutamisel kui tõlgenduserinevused, mis järeldatakse genitiivi kasutamisest kas nimisõnafraasis, klausis või koos postpositsiooniga: (40) genitiivis nimisõna on alistusseoses verbiga ning kuna verbi struktuur määrab siin argumendi suhte nimisõnaga, tõlgendatakse genitiivis nimisõna antud konstruktsioonis objektargumendina; (41) genitiivis nimisõna on alistusseoses verbiga ning kuna verbi ning antud nimisõna omavaheline seos on semantiliselt nõrgem, tõlgendatakse genitiiviga markeeritud nimisõna vaba laiendina; (42) genitiiviga markeeritud adjektiiv on alistusseoses nimisõnaga, mistõttu me tõlgendame genitiiviga markeeritud sõna vaba laiendina; (43) genitiiviga markeeritud nimisõna on alistuseoses nimisõnaga ning me tõlgendame seda seost possessiivina (ning kuna adjektiiv viitab elusale referendile, tõlgendame seda kui võõrandatavat possessiooni); (44) genitiivis nimisõna on alistusseoses postpositsiooniga ning seetõttu tõlgendame antud seost postpositsiooni konstruktsioonina.

(40) Poiss sõi jäätise (ära).

(41) Peeter viibis Londonis nädala.

(42) Me läheme väikese tiigini.

(43) Me läheme aedniku majani.

(44) aedniku kõrvale

Seega genitiiv märgib üldist alistusseost, mistõttu genitiivi kasutusel erinevates süntaktilistes funktsioonides pole muud vahet kui tõlgenduserinevused, mis järeldatakse kontekstis. Täpsema genitiiviga märgitud alistusseose ehk süntaktilise funktsiooni määravad muud tegurid, nagu ülal näidatud.

\section{Kokkuvõte}

Käesolev ülevaade tutvustas formaalsete lähenemiste kontekstis paradigmaatiliselt erinevat lähenemist käändeanalüüsile ning ka eesti keele põhikäänetele. Eesti keele põhikäänete osas väideti, et on ainult üks täiesti süntaktiline (ehk grammatiline) kääne, genitiiv, mis on sisuliselt obliikvakääne ning markeerib mittesubjektilist alistusseost mis tahes fraasipõhjaga. Võib väita, et genitiiv täidab eesti keeles seda rolli, mida akusatiiv täidab nendes keeltes, kus ta esineb. Partitiivi kääne aga käitub kirjeldatud järelduspõhise analüüsi kohaselt tõelise partitiivi käändena kogu oma kasutusalas, kuigi partitiivne tähendus võib olla hägustunud või isegi kaduma läinud, sõltuvalt kontekstilistest teguritest. Nominatiiv on aga lihtsalt käände(tunnuse) puudumine, mida ei seostata ühegi kindla süntaktilise funktsiooni või semantilise tõlgendusega.

Väljapakutud järelduspõhine käändekäsitus oli ajendatud hüpoteesist, et formaalsetes keelekirjeldusmudelites saab komplitseeritud ning homonüümiat põhjustavate käändevahelduse kirjelduste asemel ka lihtsamalt käändevaheldust seletada. Selleks pakuti süntaksipõhise käändeanalüüsi asemele morfoloogiast lähtuv analüüs, mille kohaselt käändetunnus ise lisab informat- 
siooni konstruktsioonile, kus ta esineb, ning käändega markeeritud elementide konkreetne tõlgendus tuletatakse vastastikmõjus nimisõna tähendusest, kus kääne esineb, ja verbi tähendusest, mille argument konkreetne nimisõna on, ning ka muudest kontekstilistest teguritest. Seega on konkreetsete tõlgenduste põhirõhk pandud pragmaatilisele järeldamisele, mis väidetavalt mängib väga olulist rolli käändekasutuse kujunemisel grammatiseerumisprotsessis (vt Hopper, Traugott 1993). Kui käändevahelduse kirjeldamisel kasutada pragmaatilist järeldamist süntaktilise asemel, ei ole vaja ka postuleerida keerulisi käändeomistamise mehhanisme (nagu enimlevinud süntaksimudelites, eriti aga transformatsioonigrammatikates), mis ühendaks konkreetse semantilise tõlgenduse konkreetse käändega konkreetses kontekstis, vaid piisab, kui keskenduda käändevahelduse semantilistele ning pragmaatilistele seostele ning konstruktsioonidele, kus need esinevad.

\section{Kirjandus}

A c k e r m a n, Farrell, M o o r e, John 1999. 'Telic entity' as a proto-property of lexical predicates. - The Proceedings of the LFG99 Conference. The University of Manchester. Toim Miriam Butt, Tracy Holloway King. Stanford: CSLI Publications. http://ling.ucsd.edu/ ackerman/manch-pub.pdf (16. XII 2013).

A c k e r m a n, Farrell, M o or e, John 2001. Proto-Properties and Grammatical Encoding: A Correspondence Theory of Argument Selection. Stanford: CSLI Publications.

B a e r m a n, Matthew 2009. Case syncretism. - The Oxford Handbook of Case. Toim Andrej Malchukov, Andrew Spencer. Oxford: Oxford University Press, lk 219-230.

B a k e r, Mark, V in o k u r o v a, Nadya 2010. Two modalities of case assignment: Case in Sakha. - Natural Language and Linguistic Theory, kd 28, nr 3, lk 593642.

B a r ðd a l, Jóhanna, C h e 11 i a h, Shobhana L. (toim) 2009. The Role of Semantic, Pragmatic, and Discourse Factors in the Development of Case. (Studies in Language Companion Series 108.) Amsterdam: John Benjamins.

B u t t, Miriam 2006. Theories of Case. Cambridge: Cambridge University Press.

C a h a, Pavel 2009. The Nanosyntax of Case. PhD dissertation. University of Tromsø.

C a n n, Ronnie 2007. The dynamics of case: An inferential approach to morphological case-marking. http://www.lel.ed.ac.uk/ ronnie/caseproject.pdf (16. XII 2013).

C a n n, Ronnie, Ke m p s o n, Ruth, M a rte n, Lutz 2005. The Dynamics of Language: An Introduction. Amsterdam: Elsevier.

C a n n, Ronnie, Milj a n, Merilin 2012. Differential case-marking: Syntactic descriptions and pragmatic explanations. - The Linguistic Review, kd 29, $\mathrm{nr} 4$, lk 585-605.

Chom sky, Noam 1981. Lectures on Government and Binding: The Pisa Lectures. Dordrecht: Foris Publications.

Erelt, Mati, Erelt, Tiiu, Ross, Kristiina 2007. Eesti keele käsiraamat. 3., täiendatud trükk. Tallinn: Eesti Keele Sihtasutus.

Haspelmath, Martin 2007. Pre-established categories don't exist: Con- 
sequences for language description and typology. - Linguistic Typology, kd 11, nr 1, lk 119-132.

$\mathrm{H}$ i i t a m, Katrin 2003. Definiteness and Grammatical Relations in Estonian. $\mathrm{PhD}$ dissertation. University of Manchester.

H i l b e r t, David, B e r n a y s, Paul 1939. Grundlagen der Mathematik II. Berlin: Springer.

Ho p per, Paul, Traug ott, Elizabeth Closs 1993. Grammaticalization. Cambridge: Cambridge University Press.

K e m p s o n, Ruth, M e y e r - V i o l, Wilfried, G a b b a y, Dov 2001. Dynamic Syntax: The Flow of Language Understanding. Oxford: Blackwell Publishers Ltd.

K e m p s o n, Ruth, Gre g o r o m i c h e l a ki, Eleni, H o w e s, Christine 2011. The Dynamics of Lexical Interfaces. Stanford: CSLI Publications.

Ki p a r s k y, Paul 1998. Partitive case and aspect. - The Projection of Arguments: Lexical and Compositional Factors. Toim Miriam Butt, Wilhelm Geuder. Stanford: CSLI Publications, lk 265-307.

Ki p a r sky, Paul 2001. Structural case in Finnish. - Lingua, kd 111, nr 4-7, lk 315-376.

Ko ptjevskaj a - T a m m, Maria, W ä lc h li, Bernard 2001. The Circum-Baltic languages: An areal-typological approach. - The Circum-Baltic Languages: Typology and Contact. Vol. 2. Toim Östen Dahl, Maria Koptjevskaja-Tamm. (Studies in Language Companion Series 55.) Amsterdam: John Benjamins Publishing Co, lk 615-750.

L i n d s trö m, Liina 2006. Finiitverbi asend lauses. Sõnajärg ja seda mõjutavad tegurid suulises eesti keeles. (Dissertationes filologiae estonicae Universitatis Tartuensis 16.) Tartu: Tartu Ülikooli Kirjastus.

L y o n s, Christopher 1999. Definiteness. Cambridge: Cambridge University Press.

M a r a n t z, Alec 1991. Case and licensing. - ESCOL '91: Proceedings of the Eigth Eastern States Conference on Linguistics. Ohio State University, lk 234-253.

M c Gre g o r, William B. 1998. „Optional” ergative marking in Gooniyandi revisited: Implications to the theory of marking. - Leuvense Bijdragen, $\mathrm{nr} 87$, lk 491-534.

M e t s l a n g, Helena (ilmumas). Partitive noun phrases in the Estonian core argument system. - Partitive Cases and Related Categories. Papers from the Partitives workshop (SLE Annual Meeting, September 2010). Toim Silvia Luraghi, Tuomas Huumo. Mouton de Gruyter.

Metslang, Helle 1997. Maksimaalsuse ja minimaalsuse väljendamine eesti püsiühendites. - Pühendusteos Huno Rätsepale. Toim Mati Erelt, Meeli Sedrik, Ellen Uuspõld. (Tartu Ülikooli eesti keele õppetooli toimetised 7.) Tartu: Tartu Ülikooli Kirjastus, lk 139-154.

Milj a n, Merilin, C a n n, Ronnie 2013. Rethinking case-marking and case alternation in Estonian. - Nordic Journal of Linguistics, kd 36, nr 3, lk 333-379.

M o e n s, Marc, S t e e d m a n, Mark 1988. Temporal ontology and temporal reference. - Computational Linguistics, kd 14, nr 2, lk 15-28.

M ü ü r i s e p, Kaili 2007. Süntaksiteooriad ja -mudelid. http://kodu.ut.ee/ kaili/ Loengud/Mudelid08/lnotes1.pdf (16. XII 2013).

N e l s o n, Diane C. 1995. X0 Categories and Grammatical Case Assignment in Finnish. $\mathrm{PhD}$ thesis. University of Edinburgh.

N el s o n, Diane C. 1998. Grammatical Case Assignment in Finnish. New York: Garland. 
N o r d ling e r, Rachel 1998. Constructive Case: Evidence from Australian Languages. Stanford: CSLI Publications.

Pensalfini, Robert 1999. The rise of case suffixes as discourse markers in Jingulu - a case study of innovation in an obsolescent language. - Australian Journal of Linguistics, kd 19, nr 2, lk 225-240.

R a j a n d i, Henno, M e t s l a n g, Helle 1979. Määramata ja määratud objekt. Tallinn: Valgus.

Rit ter, Elizabeth, R o s e n, Sara Thomas 2001. The interpretive value of object splits. - Language Sciences, kd 23, nr 4-5, lk 425-451.

R o o s m a a, Tiit, Ko it, Mare, M u i s chnek, Kadri, Müüris e p, Kaili, Pu o l a k a i n e n, Tiina, U i b o, Heli 2003. Eesti keele arvutigrammatika: mis on tehtud ja kuidas edasi? - Keel ja Kirjandus, nr 3, lk 192-209.

R oth stein, Susan 2004. Structuring Events: A Study in the Semantics of Lexical Aspect. Oxford: Blackwell Publishing.

Räts e p, Huno 1977. Eesti keele ajalooline morfoloogia I. Tartu: Tartu Riiklik Ülikool.

R ät s e p, Huno 1979. Eesti keele ajalooline morfoloogia II. Tartu: Tartu Riiklik Ülikool.

S p e r b e r, Dan, W il s o n, Deirdre 1995. Relevance: Communication and Cognition. 2., täiendatud trükk. Oxford: Blackwell.

Svenonius, Peter 2002. Case is uninterpretable aspect. - Proceedings of the Perspectives on Aspect Conference. Toim Henk Verkuyl. Utrecht: University of Utrecht.

V e n d l e r, Zeno 1967. Linguistics in Philosophy. Ithaca, NY: Cornell University Press.

\section{Inferential approach to the core cases in Estonian}

Keywords: theories of case, inferential pragmatics, partitive alternation, genitive, nominative

This paper presents an overview of the following arguments in Estonian, which were originally published in Cann \& Miljan (2012) and Miljan \& Cann (2013): 1) case-marking should not be treated as the passive realisation of other morphosyntactic properties of a construction but as independently bringing information to a clause; 2 ) this different view of case entails that precise functions of case-marked expressions may be determined by the interaction of the case marking, the meaning of the host noun, the semantics of any predicate of which it is an argument and other contextually given factors; more specifically; 3 ) the partitive case is semantically partitive even in alternation in grammatical contexts with nominative and genitive; 4) the completive interpretations of nominative and genitive derive from contrast with the partitive reading, rather than as being encoded in the case marking itself; 5 ) the nominative is merely the absence of case, associated with no specific positions or semantic effects; 6) the only 'structural' case in Estonian is the genitive, which marks non-subject, or oblique, dependency on some head.

Merilin Miljan (b. 1975), PhD, University of Tartu, Institute of Estonian and General Linguistics, researcher, merilin.miljan@ut.ee 